\title{
Glacier inventory and recent glacier variations in the Andes of Chile, South America
}

\author{
Gonzalo BARCAZA, ${ }^{1}$ Samuel U. NUSSBAUMER ${ }^{2,3}$ Guillermo TAPIA, ${ }^{1}$ Javier VALDÉS, ${ }^{1}$ \\ Juan-Luis GARCÍA, ${ }^{4}$ Yohan VIDELA, ${ }^{5}$ Amapola ALBORNOZ, ${ }^{6}$ Víctor ARIAS $^{7}$ \\ ${ }^{1}$ Dirección General de Aguas, Ministerio de Obras Públicas, Santiago, Chile. \\ E-mail: gbarcaza@uc.cl \\ ${ }^{2}$ Department of Geography, University of Zurich, Zurich, Switzerland \\ ${ }^{3}$ Department of Geosciences, University of Fribourg, Fribourg, Switzerland \\ ${ }^{4}$ Institute of Geography, Pontificia Universidad Católica de Chile, Santiago, Chile \\ ${ }^{5}$ Centre for Hydrology, University of Saskatchewan, Saskatoon, Canada \\ ${ }^{6}$ Department of Geology, University of Concepción, Concepción, Chile \\ ${ }^{7}$ Department of Geology, University of Chile, Santiago, Chile
}

\begin{abstract}
The first satellite-derived inventory of glaciers and rock glaciers in Chile, created from Landsat TM/ETM+ images spanning between 2000 and 2003 using a semi-automated procedure, is presented in a single standardized format. Large glacierized areas in the Altiplano, Palena Province and the periphery of the Patagonian icefields are inventoried.

The Chilean glacierized area is $23708 \pm 1185 \mathrm{~km}^{2}$, including $\sim 3200 \mathrm{~km}^{2}$ of both debris-covered glaciers and rock glaciers. Glacier distribution varies as a result of climatic gradients with latitude and elevation, with $0.8 \%$ occurring in the Desert Andes $\left(17^{\circ} 30^{\prime}-32^{\circ} \mathrm{S}\right) ; 3.6 \%$ in the Central Andes $\left(32-36^{\circ} \mathrm{S}\right), 6.2 \%$ in the Lakes District and Palena Province (36-46 $\mathrm{S}$ ), and $89.3 \%$ in Patagonia and Tierra del Fuego (46-56 $\mathrm{S}$ ). Glacier outlines, across all glacierized regions and size classes, updated to 2015 using Landsat 8 images for 98 complexes indicate a decline in areal extent affecting mostly clean-ice glaciers $\left(-92.3 \pm 4.6 \mathrm{~km}^{2}\right)$, whereas debris-covered glaciers and rock glaciers in the Desert and Central Andes appear nearly unchanged in their extent. Glacier attributes estimated from this new inventory provide valuable insights into spatial patterns of glacier shrinkage for assessing future glacier changes in response to climate change.
\end{abstract}

Keywords: glacier delineation, glacier fluctuations, glacier mapping

\section{INTRODUCTION}

A detailed glacier inventory, required to determine the importance of glaciers in the hydrologic cycle, was recommended during the International Hydrological Decade (1965-74) sponsored by UNESCO, who promoted the creation of the World Glacier Inventory (WGI) (UNESCO/ IAHS, 1970). Today, one of the recommendations of the Global Terrestrial Network for Glaciers (GTN-G) is the compilation of glacier inventory data from space-borne sensors with a repetition after a few decades, which is the typical response time of glaciers to climate change (e.g. Zemp and others, 2009). Global information on glacier area is used for estimating ice volumes, the contribution of glaciers to sea-level rise and sea-level equivalent in a context of climate change (e.g. Bahr and Radić, 2012; Huss and Farinotti, 2012; Marzeion and others, 2012; Grinsted, 2013).

Remote sensing techniques have proven to be useful for glacier inventories worldwide (e.g. Paul and others, 2009), as well as estimation of glacier changes in large areas. In spite of advances achieved following the Global Land Ice Measurements from Space (GLIMS) initiative (e.g. Raup and others, 2007), or the Randolph Glacier Inventory (RGI) (e.g. Pfeffer and others, 2014; Arendt and others, 2015), the lack of quality-controlled glacier inventories for the Southern Andes is still a source of uncertainties. Mountain glaciers and ice caps (GIC) react rapidly to climatic forcing, contributing faster than continental ice sheets to sea-level rise (IGOS, 2007, p. 34).

The Chilean glacierized area was estimated to be $\sim 20715 \mathrm{~km}^{2}$ (Casassa, 1995). The glacierized area of the Southern Andes (south of $25^{\circ} \mathrm{S}$ ), covering $\sim 3 \%$ of the total area of worldwide GIC, mostly lies in Chile. Despite the importance of Chilean glaciers as representatives of the Southern Andes, the inventory work was up to now still uncompleted. The usefulness of sparse glacier inventories obtained with different data and methods is much less than that of one inventory in a standardized format based on international recommendations (i.e. Paul and others, 2009). Since the use of Landsat Thematic Mapper (TM) and Enhanced Thematic Mapper $(\mathrm{ETM}+)$ data from the year $2000( \pm 5$ years) is recommended (i.e. Paul and others, 2009), we selected Landsat images close to late-summer 2003, prior the failure of the Scan-Line Corrector (SLC-Off) for our observation period.

Glacier changes are connected to global warming and contribute to run-off. It is well known that debris-covered glaciers and rock glaciers are less sensitive to ablation than clean-ice glaciers so their changes may alter spatial patterns (e.g. Benn and others, 2012) of mass loss if they predominate in a 
certain catchment. Therefore, a quantitative and detailed inventory of these ice masses provides important information needed to assess future area changes in response to global warming.

In this paper, we present the results of the first complete glacier inventory in Chile. The inventory was carried out using Landsat TM and ETM+ images acquired primarily close to late-summer 2003; the Shuttle Radar Topographic Mission (SRTM) DEM; a semi-automatic procedure to define glacier outlines; and an unsupervised classification method ( $k$-means) to estimate clean-ice or debris-covered area.

\section{Study area}

Chile extends along the Southern Andes over $4000 \mathrm{~km}$ $\left(17^{\circ} 30^{\prime}-56^{\circ} \mathrm{S}\right)$, occupying mostly its western side (Fig. 1). The elevation of the Andes Cordillera decreases southwards from peaks in excess of $6000 \mathrm{~m}$ in the Dry Andes $\left(17^{\circ} 30^{\prime}-36^{\circ} \mathrm{S}\right)$ to mountains dissected by fjords and channels in the Wet Andes (36-56 S) (Lliboutry, 1998). This large extent in both latitude and elevation creates a natural diversity for the occurrence of glaciers, which can be classified in the following main zones: (i) Desert Andes; (ii) Central Andes; (iii) Lakes District and Palena Province; and (iv) Patagonian Andes and Tierra del Fuego (Lliboutry, 1998).

The Desert Andes zone extends from the northern boundary of Chile to the Choapa basin $\left(\sim 17^{\circ} 30^{\prime}-32^{\circ} \mathrm{S}\right)$. The transition in climate from hyper-arid conditions in Norte Grande to semi-arid ones in Norte Chico (Ginot and others, 2006; Favier and others, 2009) is defined by the South American Arid Diagonal (19-29 ${ }^{\circ}$ S), hereafter Arid Diagonal, which separates summer precipitation patterns driven from the Tropics to the north, and winter precipitation driven by the westerlies to the south (Garreaud, 2009).

At Norte Grande, an intermountain high plateau so-called Altiplano, a distinct wetter region within the Desert Andes, is characterized by inland drainage (endorheic drainage basin). Surface water discharging to the sea in catchments with a clear perimeter is found only from Norte Chico $\left(28^{\circ} 30^{\prime} \mathrm{S}\right)$ and southward, which includes Copiapó, Huasco, Elqui, Limarí and Choapa catchments (Favier and others, 2009). Puna de Atacama $\left(\sim 27^{\circ} \mathrm{S}\right)$ is another inner high and arid plateau containing also inland drainage, a branch of Altiplano found eastward of Atacama Desert.

The Central Andes (32-36 $\mathrm{S})$ including Petorca, Aconcagua, Maipo, Rapel, Maule and Mataquito catchments, are characterized by Mediterranean climate with wet winters (April-September) and dry summers (OctoberMarch). South of Itata river $\left(36^{\circ} \mathrm{S}\right)$, the elevation of the Andes range sharply decreases and a wetter climate prevails at Lakes District, where isolated ice-covered volcanoes can be found down to Petrohué catchment $\left(41^{\circ} \mathrm{S}\right)$.

South of Reloncaví inlet, along the so-called Palena Province $\left(41^{\circ} 30^{\prime}-44^{\circ} \mathrm{S}\right)$, the Andes range is dissected by fjords characterizing a deeply indented glacierized rocky coastline. A series of archipelagos which stretches along the western coast of Patagonia means fewer large catchments such as Puelo, Yelcho, Palena and Aysén.

The Patagonian Andes and Tierra del Fuego, from Río Aysén to Cape Horn (46-56 S) are characterized by a larger amount of annual rainfall well distributed throughout the year and a strong west-east gradient (e.g. Ohata and others, 1985; Carrasco and others, 2002). The Northern

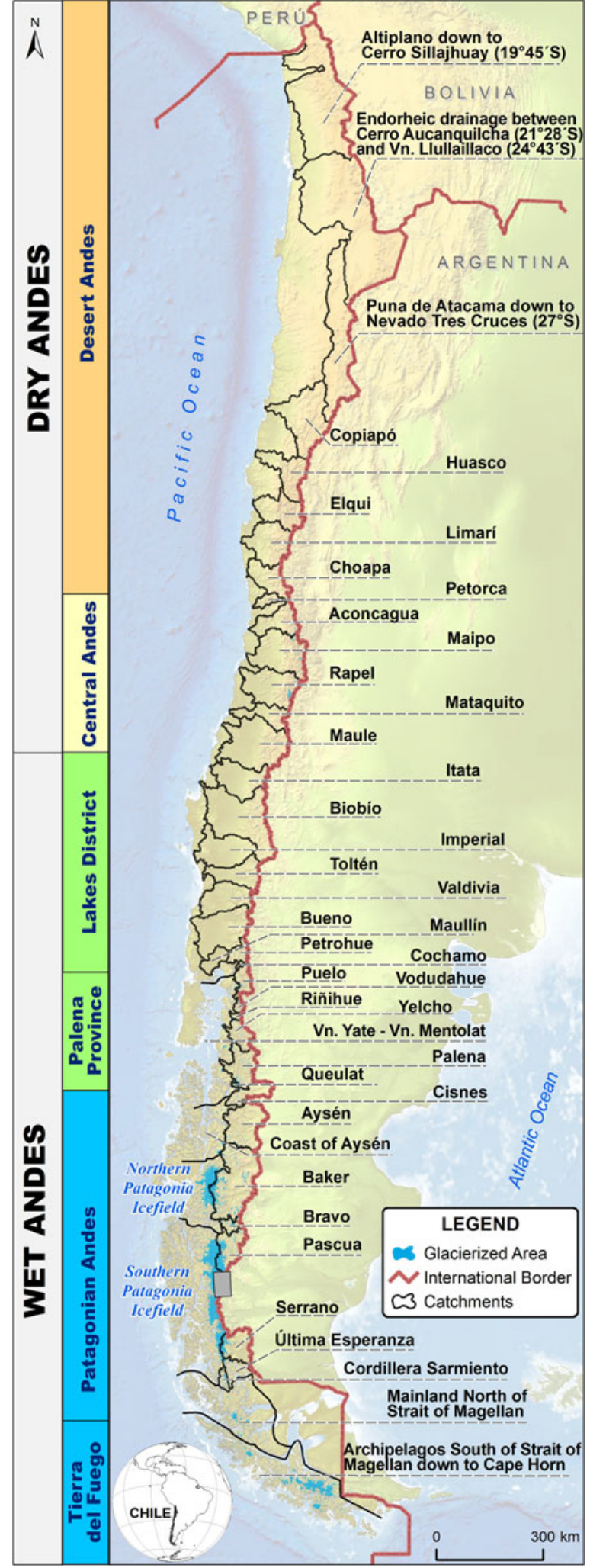

Fig. 1. Chile extends along the Southern Andes for over $4000 \mathrm{~km}$ $\left(17^{\circ} 30^{\prime}-56^{\circ} \mathrm{S}\right)$, occupying mostly its western side. Elevation of the Andes Cordillera decreases southwards from peaks in excess of $6000 \mathrm{~m}$ in the Dry Andes $\left(17^{\circ} 30^{\prime}-36^{\circ} \mathrm{S}\right)$ to mountains dissected by fjords and channels in the Wet Andes (36-56 S). Main glaciological zones according to Lliboutry (1998): (i) Desert Andes; (ii) Central Andes; (iii) Lakes District and Palena Province; and (iv) Patagonian Andes and Tierra del Fuego.

Patagonia Icefield (NPI) and the Southern Patagonia Icefield (SPI) are the largest temperate ice-bodies of the Southern Hemisphere (Warren and Sugden, 1993). 
Although most of the SPI lies in Chile, it is partially shared with Argentina (Casassa and Rivera, 2001), existing within its eastern side a rectangle (Mount Fitz Roy - Cerro Murallón), in which the boundary is not defined yet. In the periphery of the Patagonian icefields, mountain glaciers are found at Baker, Pascua and Serrano catchments, the three main large catchments, which drain meltwater from the east side of the icefields to the Pacific Ocean.

\section{Climatic setting}

Meteorological stations from the Dirección General de Aguas (DGA), the official water agency of Chile, are used to characterize the climatic setting of main glaciological zones (Lliboutry, 1998). At Visviri station $\left(17^{\circ} 36^{\prime} \mathrm{S} / 69^{\circ} 28^{\prime} \mathrm{W}\right.$; $\sim 4080 \mathrm{~m}$ a.s.l.) located in the Altiplano, the mean annual air temperature (MAAT) is $5{ }^{\circ} \mathrm{C}$ and the total precipitation up to $350 \mathrm{~mm} \mathrm{a}^{-1}$ is concentrated in summer (January-March) whereas the winter (May-September) is dry. In Norte Chico, at Embalse La Laguna station $\left(30^{\circ} 12^{\prime} \mathrm{S} / 70^{\circ} 2^{\prime} \mathrm{W}\right.$; $\sim 3150 \mathrm{~m}$ a.s.I.), the MAAT is $8^{\circ} \mathrm{C}$ and the precipitation is concentrated in winter (July-October) with a lesser amount of $200 \mathrm{~mm} \mathrm{a}^{-1}$. At Embalse El Yeso station $\left(33^{\circ} 40^{\prime} \mathrm{S} / 70^{\circ} 5^{\prime} \mathrm{W}\right.$; $\sim 2400 \mathrm{~m}$ a.s.l.), in the Central Andes, the MAAT is $8.3^{\circ} \mathrm{C}$ and precipitation, up to $515 \mathrm{~mm} \mathrm{a}^{-1}$, is concentrated in winter.

At Puelo station $\left(41^{\circ} 39^{\prime} \mathrm{S} / 72^{\circ} 17^{\prime} \mathrm{W} ; \sim 0 \mathrm{~m}\right.$ a.s.l.) in the Lakes District, the MAAT is $11.4{ }^{\circ} \mathrm{C}$ while the precipitation, evenly distributed throughout the year, greatly increases to $3066 \mathrm{~mm} \mathrm{a}^{-1}$. In the Patagonian icefields, at Laguna San Rafael $\left(46^{\circ} 38^{\prime} \mathrm{S} / 73^{\circ} 52^{\prime} \mathrm{W} ; \sim 0 \mathrm{~m}\right.$ a.s.l.) the MAAT of $6.9^{\circ} \mathrm{C}$ indicates a warm climate with a total precipitation of $3144 \mathrm{~mm} \mathrm{a}^{-1}$ on the west side because of maritime influence. However, the MAAT of $4.9^{\circ} \mathrm{C}$ and lesser precipitation of $1649 \mathrm{~mm} \mathrm{a}^{-1}$ at Lake Colonia Station $\left(47^{\circ} 20^{\prime} \mathrm{S} / 73^{\circ} 6^{\prime} \mathrm{W}\right.$; $\sim 150 \mathrm{~m}$ a.s.l.) indicates a cold steppe on the continental east side of the Andes.

\section{Previous glacier inventories}

Based upon vertical aerial photographs taken in 1955 and 1961, glacier inventories were carried out in catchments of the Dry Andes (Garín, 1987); Central Andes (Caviedes, 1979; Marangunic, 1979; Valdivia, 1984; Noveroy, 1987); and Lakes District (Rivera, 1989). These studies covered only ca. $1365 \mathrm{~km}^{2}$, i.e. $\sim 6 \%$ of the total glacierized area, distributed in 1751 individual glaciers inventoried. Rock glaciers inventoried are limited to the Altiplano between $18^{\circ} \mathrm{S}$ and $29^{\circ} \mathrm{S}$ (i.e. Kammer, 1998; Payne, 1998). Other catchments with data available are Huasco (Nicholson and others, 2009) and Aconcagua (Bown and others, 2008).

In the Wet Andes, outlet glaciers of Patagonia were inventoried due to their scientific importance such as their location in mid-latitudes and temperate ice conditions. Satellite images acquired in 1986 and after 2000, were used within the NPI (Aniya, 1988; Rivera and others, 2007), the SPI (Aniya and others, 1996), Gran Campo Nevado (Schneider and others, 2007) and Isla Riesco (Casassa and others, 2002).

Existing glacier inventories estimated a glacierized area varying between $20715 \mathrm{~km}^{2}$ (Casassa, 1995) and 20575 $\mathrm{km}^{2}$ (Rivera and others, 2002). These compilations included the catchments inventoried by DGA, the inventories for both the icefields (Aniya, 1988; Aniya and others, 1996), and an estimate of ca. $5300 \mathrm{~km}^{2}$ of the total area not inventoried in Palena Province and of mountain glaciers in the periphery of the Patagonian icefields (i.e. Casassa, 1995; Rivera and others, 2000; Rivera and others, 2002).

\section{DATA AND METHODS}

\section{Datasets}

We selected 35 Landsat Thematic Mapper (TM) and Enhanced Thematic Mapper (ETM+) images at Level 1 downloaded from the United States Geological Survey (USGS) website spanning between 2000 and 2003 (Table 1). Images with minimum clouds and mostly acquired in late-summer season were selected.

\section{Glacier outlines}

To identify clean-ice using multispectral data, the band ratio applied to digital numbers (DN) of bands TM3 $(0.63-0.69 \mu \mathrm{m})$ and TM5 (1.55-1.75 $\mu \mathrm{m})$ was used as classification method. Subsequently, a $3 \times 3$ kernel median filter was applied to remove isolated pixels corresponding to rocks on the glacier or snow-cover nearby glacier outlines. The threshold value was obtained from the histogram of each ratio image to discriminate clean-ice and snow surfaces from surrounding terrain (Fig. 2).

Despite improved algorithms, automatic classification of debris-covered glaciers and rock glaciers is still challenging and a main source of inaccuracies (Paul and others, 2013). While a debris-covered glacier (i.e. valley glacier) has continuous coverage of supra-glacial debris across its width in the ablation zone (Kirkbride, 2011), a rock glacier contains interstitial ice (Müller and others, 1977) or a matrix of ice, showing evidence of past or present flow (Cogley and others, 2011). An important clue to distinguish debriscovered glaciers from rock glaciers is the existence of cleanice exposed in supraglacial lakes and surface depressions on debris-covered glaciers (e.g. Sakai and others, 2000; Benn and others, 2012) whereas rock glaciers are identified by their steep fronts and distinctive series of ridges and furrows perpendicular to the direction of flow (Giardino and others, 2011). Debris-covered glaciers and rock glaciers were manually digitized on screen using Band 8 at $15 \mathrm{~m}$ spatial resolution (Fig. 2). Manual editing was also supported by aerial photographs taken in 1996/97 as well as ground, maritime and aerial observations between Tacora and Llullaillaco volcanoes; the catchments of Copiapó, Elqui, Aconcagua, Maipo, Rapel and Petrohué; and both NPI and SPI.

\section{Minimum threshold}

Using Landsat $30 \mathrm{~m}$ pixel size images, a minimum threshold of $0.01 \mathrm{~km}^{2}$ (1 hectare) has been recommended for the identification of glaciers (Paul and others, 2009). We used the threshold value of $0.01 \mathrm{~km}^{2}$, which has been widely used for glacier inventories (e.g. Kääb and others, 2002; Paul and Andreassen, 2009; Bliss and others, 2013; Pfeffer and others, 2014). However, mountain groups located between Aucanquilcha and Llullaillaco volcanoes, in the driest part of the Arid Diagonal, were excluded from the analyses to avoid the inclusion of patchy snow cover in the Dry Andes.

\section{Parameters inventoried}

We used the UNESCO classification and description (Müller and others, 1977) to define glacier variables to be inventoried 
Table 1. Landsat Thematic Mapper (TM), Enhanced Thematic Mapper (ETM+) and Operational Land Imager (OLI) images used in this study

\begin{tabular}{|c|c|c|c|c|c|}
\hline Catchment & Sensor & Path & Row & Date & Image ID \\
\hline \multirow[t]{5}{*}{ Altiplánicas - Sillajhuay } & ETM+ & 002 & 072 & $2002-11-30$ & LE70020722002334COA00 \\
\hline & OLI & 001 & 073 & 2015-12-05 & LC80010732015339LGN00 \\
\hline & ETM+ & 001 & 073 & $2002-12-25$ & LE70010732002359PFS01 \\
\hline & ETM+ & 001 & 074 & 2002-08-19 & LE70010742002231PFS00 \\
\hline & OLI & 001 & 074 & $2015-11-20$ & LC80010742015323LGN00 \\
\hline \multirow[t]{2}{*}{ Aucanquilcha - Llullaillaco } & ETM+ & 233 & 075 & 2003-03-08 & LE72330752003067COA01 \\
\hline & ETM+ & 233 & 077 & $2003-03-24$ & LE72330772003083EDC00 \\
\hline Puna de Atacama & ETM+ & 233 & 078 & 2000-02-12 & L72233078_07820000212 \\
\hline \multirow[t]{2}{*}{ Copiapó } & ETM+ & 233 & 079 & 2002-03-21 & LE72330792002080EDC00 \\
\hline & OLI & 233 & 079 & 2015-05-03 & LC82330792015044LGN00 \\
\hline \multirow[t]{2}{*}{ Huasco } & ETM+ & 233 & 080 & 2003-01-03 & LE72330802003003PFS00 \\
\hline & OLI & 233 & 080 & 2015-03-18 & LC82330802015076LGN00 \\
\hline Elqui - Limarí & ETM+ & 233 & 081 & 2003-04-09 & L72EDC1103099170300 \\
\hline \multirow[t]{3}{*}{ Aconcagua - Maipo } & ETM+ & 233 & 083 & $2003-03-24$ & LE72330832003083EDC00 \\
\hline & ETM+ & 233 & 083 & 2003-04-09 & LE72330832003099EDC00 \\
\hline & OLI & 233 & 083 & 2015-02-13 & LC82330832015044LGN01 \\
\hline \multirow[t]{2}{*}{ Rapel - Mataquito } & ETM+ & 232 & 084 & $2003-03-17$ & LE72320842003076EDC00 \\
\hline & OLI & 232 & 084 & 2015-03-10 & LC82320842015069LGN01 \\
\hline \multirow[t]{3}{*}{ Maule } & ETM+ & 233 & 085 & 2003-03-24 & L72233085_08520030324 \\
\hline & ETM+ & 232 & 085 & 2003-03-17 & LE72320852003076EDC00 \\
\hline & OLI & 233 & 085 & 2015-04-02 & LC82330852015092LGN00 \\
\hline \multirow[t]{4}{*}{ Itata - Bío-Bío - Toltén } & ETM+ & 233 & 086 & 2003-03-24 & L72233086_08620030324 \\
\hline & OLI & 233 & 086 & 2015-03-18 & LC82330862015076LGN00 \\
\hline & ETM+ & 232 & 087 & 2001-02-07 & L72232087_08720010207 \\
\hline & OLI & 233 & 087 & 2015-05-03 & LC82330872015044LGN00 \\
\hline \multirow[t]{2}{*}{ Valdivia - Bueno } & ETM+ & 232 & 088 & 2001-04-12 & L72232088_08820010412 \\
\hline & OLI & 232 & 088 & $2015-03-26$ & LC82320882015085LGN00 \\
\hline Petrohué - Puelo - Inexplorado & ETM+ & 232 & 089 & 2003-03-17 & L72232089_08920030317 \\
\hline & OLI & 232 & 090 & 2015-02-22 & LC82320902015053LGN01 \\
\hline \multirow[t]{2}{*}{ Palena - Cisnes - Aysén } & ETM+ & 232 & 091 & 2000-03-08 & L72232091_09120000308 \\
\hline & OLI & 232 & 091 & 2015-02-22 & LC82320912015053LGN01 \\
\hline \multirow[t]{3}{*}{ Aysén - Baker } & ETM+ & 232 & 092 & 2000-03-08 & L72232092_09220000308 \\
\hline & OLI & 232 & 092 & 2015-03-26 & LC82320922015085LGN00 \\
\hline & ETM+ & 231 & 093 & 2002-01-18 & LE72310932002018EDC00 \\
\hline \multirow[t]{2}{*}{ Northern Patagonia Icefield } & ETM+ & 232 & 093 & 2001-03-11 & L72232093_09320010311 \\
\hline & OLI & 232 & 093 & 2015-04-11 & LC82320932015101LGN00 \\
\hline \multirow[t]{2}{*}{ East of Southern Patagonia Icefield } & ETM+ & 232 & 094 & 2003-04-02 & L72232094_09420030402 \\
\hline & OLI & 232 & 094 & 2015-05-08 & LC82320942015021LGN00 \\
\hline \multirow[t]{2}{*}{ Southern Patagonia Icefield (North) } & TM & 231 & 094 & 2001-03-12 & LT52310942001071COA00 \\
\hline & OLI & 231 & 094 & 2015-05-10 & LC82310942015014LGN00 \\
\hline \multirow[t]{2}{*}{ Southern Patagonia Icefield (Central) } & TM & 231 & 095 & 2001-03-12 & LT52310952001071COA00 \\
\hline & OLI & 231 & 095 & 2015-05-10 & LC82310952015014LGN00 \\
\hline Southern Patagonia Icefield (South) & TM & 231 & 096 & 2001-03-12 & LT52310962001071COA00 \\
\hline Gran Campo Nevado - Isla Riesco & ETM+ & 231 & 096 & 2001-05-07 & L72231096_09620010507 \\
\hline & OLI & 231 & 096 & 2015-09-27 & LC82310962015270LGN00 \\
\hline & ETM+ & 230 & 097 & $2002-03-16$ & L72230097_09720020316 \\
\hline & ETM+ & 226 & 098 & 2003-02-19 & LE72260982003050EDC00 \\
\hline Cordillera Darwin & ETM+ & 228 & 098 & $2001-03-31$ & LE72280982001090EDC00 \\
\hline & ETM+ & 227 & 098 & $2003-03-30$ & LE72270982003089EDC00 \\
\hline & ETM+ & 229 & 098 & $2001-03-28$ & L71AGS1103087210200 \\
\hline & OLI & 227 & 098 & 2015-03-23 & LC82270982015082LGN01 \\
\hline
\end{tabular}

in line with international recommendations (Paul and others, 2009). The basic information includes: identification code following WGI; name of the glacier; primary classification of WGl; datum; coordinates; catchment code; acquisition date; inventory date; glacier surface area; exposed area (clean-ice); debris-covered area; mean width and length; orientation; and mean elevation.

\section{Glacier catchments}

We used the catchment classification data base of DGA (Benitez, 1980) as a hydrographic unit. Because this classification is based on large topographic maps (1:250 000), we improved it by means of the ArcGIS Watershed module. In the absence of surface water, natural regions such as Altiplano and Puna de Atacama were determined 

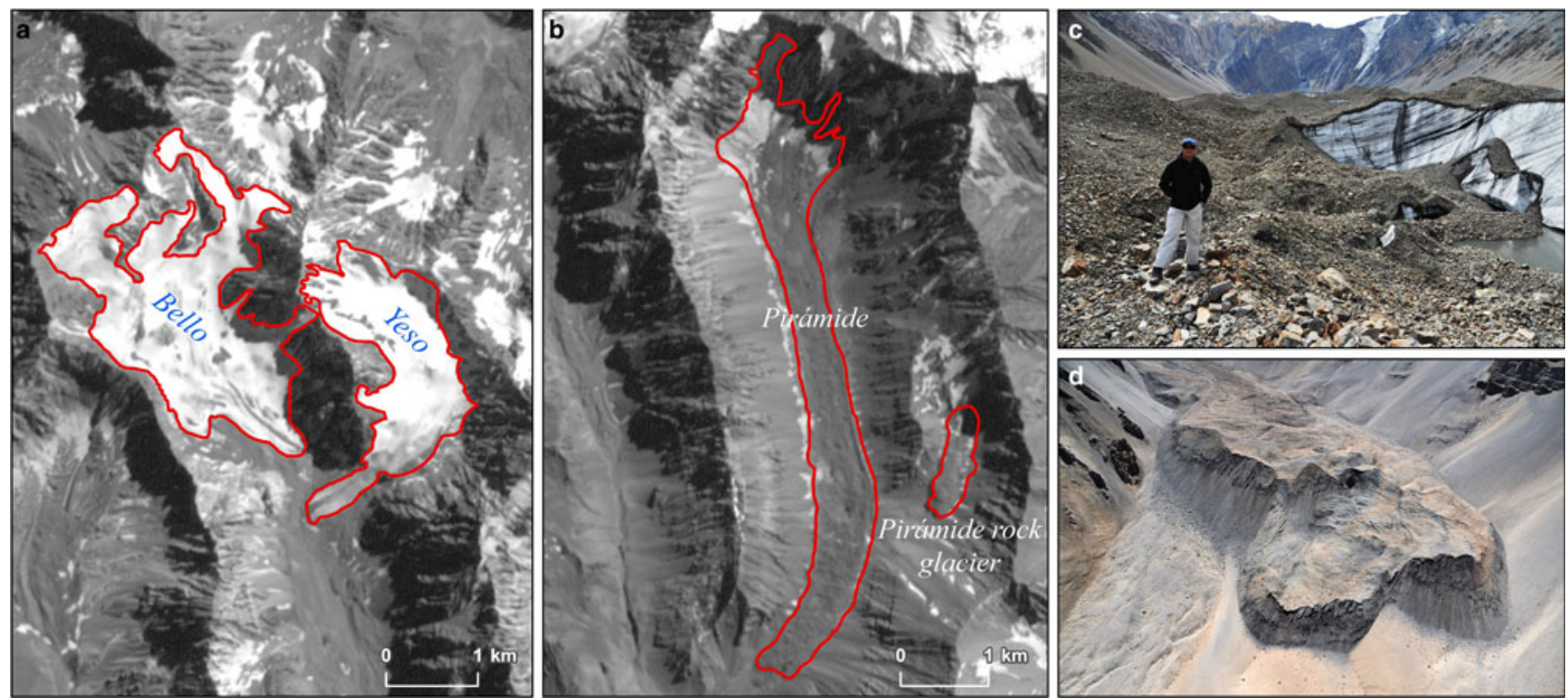

Fig. 2. Glacier outlines for Bello and Yeso (a) glaciers (clean-ice), Pirámide debris-covered glacier and Rocoso Pirámide rock glacier (b) in the Maipo catchment, Central Andes, as seen in Landsat ETM+ image (24 March 2003). The band ratio of bands TM3 and TM5 and a threshold value were used to discriminate clean-ice from surrounding terrain. Supported by ground observations, debris-covered glaciers and rock glaciers were manually digitized on screen using Band 8 at 15-m spatial resolution. Note the existence of clean-ice exposed in the supraglacial lake and surface depression on the Pirámide debris-covered glacier (c) and the steep front and distinctive series of ridges and furrows of Pirámide rock glacier (d). Location of glaciers is shown in Figure 3.

following distinctive peaks instead of catchments. In cases of very small catchments at the archipelagic west coast of Palena Province and Patagonia, glacier complexes were labeled per specific rivers, peaks or fjords.

Outlet glaciers were labeled according to contiguity to the icefield and size of the drainage area (Aniya and others, 1996). Mountain glaciers other than outlets were grouped as those connected with the icefield but facing away from its main body; and remaining mountain glaciers contributing to a large catchment (e.g. Baker, Pascua and Serrano) but unconnected with its main body were labeled as other than icefields. In the case of SPI, outlets glaciers contributing to the Pacific Ocean were labeled separately from those outlets flowing to the east side, and the rectangle defined by the boundary Agreement of 1998 was excluded. The Strait of Magellan represents a natural division between mainland and the archipelagic area down to Cape Horn.

\section{Glacier classification}

The primary morphological classification of UNESCO (Müller and others, 1977; Digit 1) was adopted to distinguish different types of glaciers. However, and beyond Müller and others (1977), the distinction between cleanice and debris-covered areas as well as land-terminating and calving glaciers is an important issue for massbalance considerations. A threshold of $0.25 \mathrm{~km}^{2}$ (Cogley and others, 2011) was used to further distinguish between glacierets $\left(<0.25 \mathrm{~km}^{2}\right)$ and glaciers $\left(>0.25 \mathrm{~km}^{2}\right)$. We added size intervals ranging between 0.05 and 0.25 $\mathrm{km}^{2}$ for discussion and analyses. Ice-bodies smaller than $0.05 \mathrm{~km}^{2}$, including rock glaciers, snowfields or snowpatches are considered to be objects made mainly by ice that may or may not be a glacier (Cogley and others, 2011).

\section{Recent glacier variations}

Glacier outlines for 98 large representative glacier complexes across all glacierized regions and size classes were updated to 2015 using 21 Landsat 8 Operational Land Imager (OLI) images (Table 1). Glacier area variations since 2000/03 were determined by comparing changes in terminus position as visible in the imagery for the different periods. The glaciers sampled represent an area of $7461.8 \pm 373 \mathrm{~km}^{2}$ in $2000 / 03$, which is $\sim 31 \%$ of glacierized area, including glaciers of different characteristics such as rock glaciers and debris-covered glaciers as well as land-terminating and calving glaciers (clean-ice).

\section{Error estimation}

Since most of the estimated glacierized area was measured for the first time, we estimated a measurement error based upon outline perimeter and the size of the pixel. In case of clean-ice glaciers these measurements yield an error of $\sim 2 \%$. However, assuming a worst case scenario for debriscovered glaciers and rock glaciers, this error was enlarged to $5 \%$ as a representative error. In addition to delineation method, other potential error sources are co-registration, scene quality, clouds, seasonal snow, shadow, drainage divides in the accumulation region or glacier terminus with dead ice (e.g. Paul and others, 2009; Bolch and others, 2010; Paul and others, 2013). All these potential errors were minimized by means of manual editing.

\section{RESULTS AND DISCUSSION}

Glaciers occur from Tacora volcano in the Altiplano southward to Isla Hoste at Cape Horn (Figs. 3 and 4). Glacier distribution varies due to topographical factors and climate determined by latitude and the elevation of the Andes. Whereas ice-bodies in the Dry Andes are located at high 

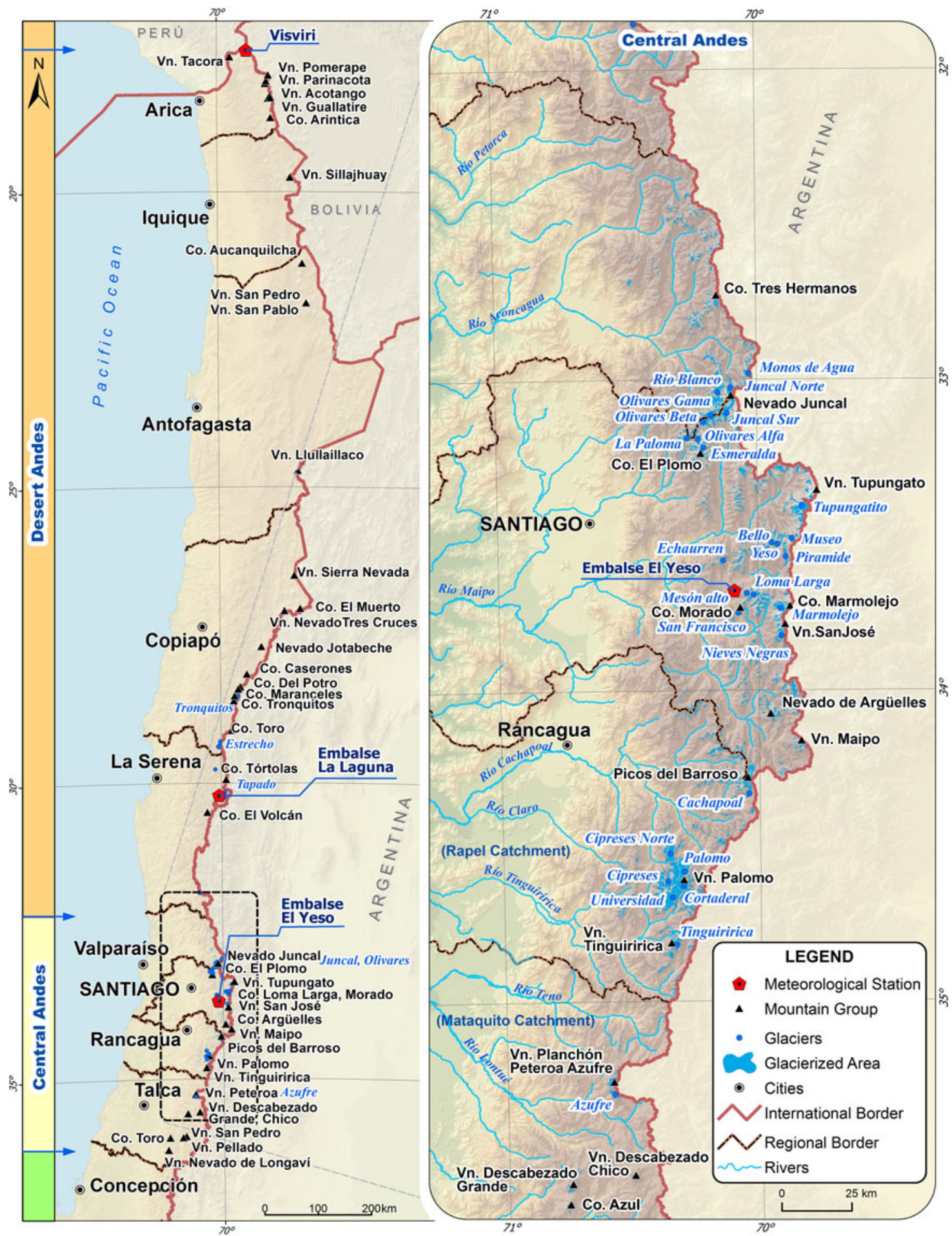

Fig. 3. Glacier distribution in the Desert Andes $\left(17^{\circ} 30^{\prime}-32^{\circ} \mathrm{S}\right)$ and Central Andes $\left(32-36^{\circ} \mathrm{S}\right)$. Glacier distribution varies as a result of latitudinal climate and elevation gradients, occurring $188.9 \mathrm{~km}^{2}$ in the Desert Andes and $869.5 \mathrm{~km}^{2}$ in the Central Andes. Mountain groups and individual glaciers are shown.

altitude, glaciers in the Wet Andes reach down to sea-level. Figure 5 depicts the predominance of glaciers of $0.01-1 \mathrm{~km}^{2}$ around $3700 \mathrm{~m}$ a.s.l. in the Central Andes $\left(30-35^{\circ} \mathrm{S}\right)$, while glaciers larger than $10 \mathrm{~km}^{2}$ occur between 800 and $2000 \mathrm{~m}$ a.s.l. and are concentrated in the Patagonian Andes and Tierra del Fuego $\left(43-56^{\circ} \mathrm{S}\right)$.

San Rafael (ca. $\left.724 \mathrm{~km}^{2}\right)$, an outlet glacier of the NPI is the lowest latitude tidewater glacier. Pio XI, an outlet glacier on the west side of the SPI is the largest glacier, with an area of $1246 \mathrm{~km}^{2}$. It is the only glacier larger than $1000 \mathrm{~km}^{2}$, and accounts alone for $5.2 \%$ of the total glacierized area.
Glaciers (ice-bodies) inventoried were morphologically classified into five main types: icefield and outlet, valley, mountain, glacierets and snowfields, and rock glaciers.

\section{Glacier number and areas}

The inventory contains 24005 ice-bodies larger than 0.01 $\mathrm{km}^{2}$, covering an area of $23708 \pm 1185 \mathrm{~km}^{2}$, which corresponds to ca. $3.1 \%$ of the Chilean territory. The results are presented as total number of glaciers and glacierized area 


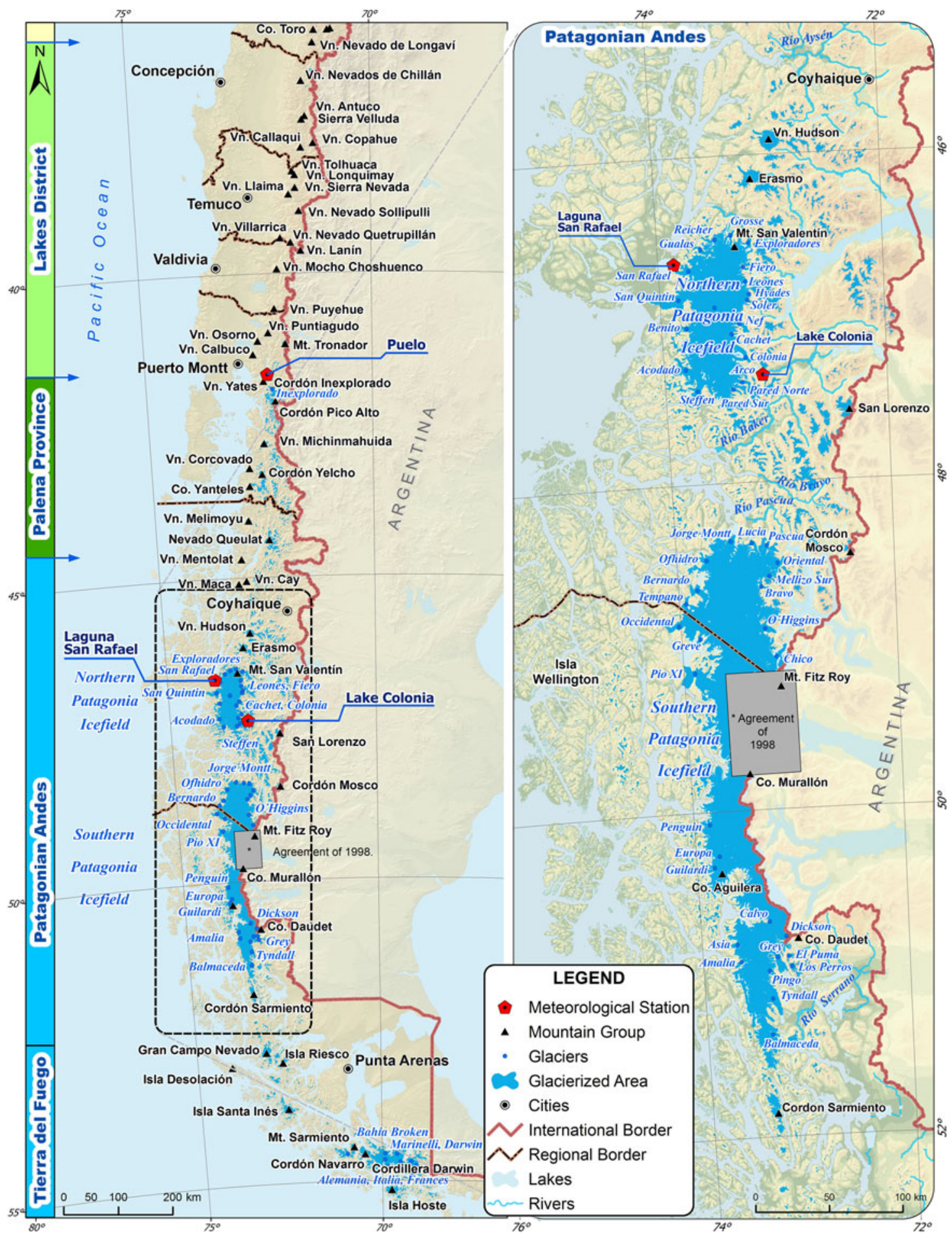

Fig. 4. Glacier distribution in the Lakes District and Palena Province $\left(36-46^{\circ} \mathrm{S}\right)$ and Patagonia and Tierra del Fuego $\left(46-56^{\circ} \mathrm{S}\right)$. Glaciers from Itata to Cisnes catchments cover $1478.8 \mathrm{~km}^{2}$ and $21171 \mathrm{~km}^{2}$ occurs from Aysén catchment southwards, along the Patagonian Andes and Tierra del Fuego. Mountain groups and individual glaciers are shown.

by glaciological zone, region and catchment (Table 2) and as number of glaciers per size class (Table 3).

Uncertainties in the final inventory are due to the occurrence of snowfields that may remain for more than two summer seasons, the absence of ice flow or the lack of current ice in a rock glacier. All these uncertainties are more critical in ice-bodies smaller than $0.05 \mathrm{~km}^{2}$. Although misclassification of rock glaciers does not largely alter the total glacierized area (e.g. $259.4 \mathrm{~km}^{2}$ ), the inclusion of small ice-bodies largely hampers the number of glaciers inventoried (e.g. 10707 glaciers are smaller than $0.05 \mathrm{~km}^{2}$ ). If ice-bodies smaller than 0.05 $\mathrm{km}^{2}$ are excluded, the number of ice-bodies decreases to 13298 , with a decrease of $3 \%$ in area yielding a glacierized area of $23448 \pm 1172 \mathrm{~km}^{2}$.

When all the glacierets are excluded $\left(<0.25 \mathrm{~km}^{2}\right)$, the total number of 5748 glaciers yields a glacierized area of $22567 \pm$ $1128 \mathrm{~km}^{2}$, which lies within the error estimates for satellitederived inventories. Therefore, a decrease of $75 \%$ in number of ice-bodies only implies a decrease of $5 \%$ in glacierized 

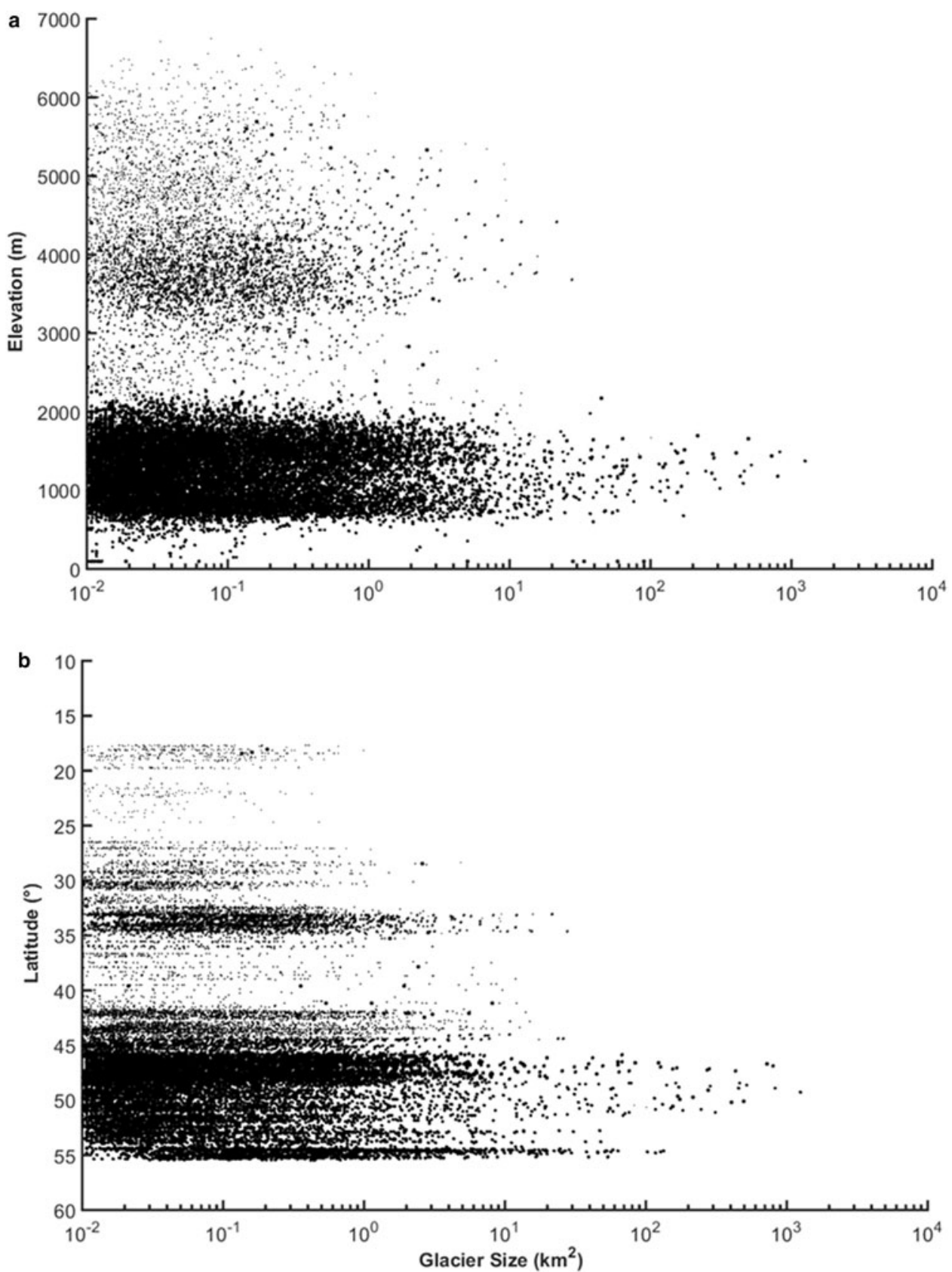

Fig. 5. Glacier size vs mean elevation for glaciers inventoried (a) and glacier size vs southern latitude (b). Smaller ice-bodies are found at high altitude in the Desert Andes over $4000 \mathrm{~m}$ a.s.I. whereas the largest glaciers are found in the Patagonian Andes, where outlets reach the sea. $X$-axes in both figures are plotted in logarithmic scale.

area. Consequently, based on a decadal-scale glacier inventory, a threshold value of $0.01 \mathrm{~km}^{2}$ can be misleading and time consuming due to rapid glacier changes, and a threshold value of $0.05 \mathrm{~km}^{2}$ is preferable.

\section{Minimum threshold}

The minimum threshold used determines the number of small ice-bodies $\left(<0.05 \mathrm{~km}^{2}\right)$. To reduce errors in sea-level rise estimates, a glacier inventory using a threshold down to $0.01 \mathrm{~km}^{2}$ is required to consider the significant contribution from very small glaciers (Bahr and Radić, 2012). However, at those scales the difference between glaciers and snowpatches is blurred (Bahr and Radić, 2012).

The minimum threshold varies in existing inventories worldwide depending on objectives and resources available
(Pfeffer and others, 2014). Different threshold values have been used: $0.01 \mathrm{~km}^{2}$ at the Antarctic Peninsula (Bliss and others, 2013); $0.02 \mathrm{~km}^{2}$ for Western Himalaya (Frey and others, 2012); $0.1 \mathrm{~km}^{2}$ (Schiefer and others, 2008) and $0.05 \mathrm{~km}^{2}$ for British Columbia (Bolch and others, 2010) and $0.05 \mathrm{~km}^{2}$ for northern Patagonia (Paul and Mölg, 2014). The division of an ice-complex into individual glaciers can also significantly make the number of glaciers vary; therefore it can be an arbitrary quantity (Pfeffer and others, 2014) with the glacier surface area being the most important parameter.

\section{Glacier distribution by zones}

\section{Desert Andes}

Glaciers and rock glaciers of the Desert Andes cover 188.9 $\mathrm{km}^{2}$, representing about $0.8 \%$ of the Chilean glacierized area, 
Table 2. Total number and area of inventoried glaciers by zone, region and catchment using 2000/03 Landsat data

\begin{tabular}{|c|c|c|c|c|c|}
\hline & Zone & Region & Catchment & Number & $\begin{array}{l}\text { Area } \\
\mathrm{km}^{2}\end{array}$ \\
\hline \multirow{9}{*}{$\begin{array}{l}\text { Dry } \\
\text { Andes }\end{array}$} & \multirow[t]{4}{*}{ Desert Andes } & \multirow[t]{3}{*}{ Norte Grande } & Altiplano down to Cerro Sillajhuay $\left(19^{\circ} 45^{\prime} \mathrm{S}\right)$ & 373 & 36.2 \\
\hline & & & $\begin{array}{l}\text { Endorheic basins between Cerro Aucanquilcha } \\
\left(21^{\circ} 28^{\prime} \mathrm{S}\right) \text { and } \mathrm{Vn} \text {. Llullaillaco }\left(24^{\circ} 43^{\prime} \mathrm{S}\right)\end{array}$ & 93 & 5.1 \\
\hline & & & $\begin{array}{l}\text { Puna de Atacama down to Nevado Tres Cruces } \\
\left(27^{\circ} \mathrm{S}\right)\end{array}$ & 257 & 21.0 \\
\hline & & Norte Chico & Copiapó - Choapa & 1334 & 126.6 \\
\hline & Central Andes & Central Andes & Petorca - Maule & 2624 & 869.5 \\
\hline & \multirow{4}{*}{$\begin{array}{l}\text { Lakes District and } \\
\text { Palena Province }\end{array}$} & Lakes District & Itata - Cochamó & 447 & 193.3 \\
\hline & & \multirow[t]{3}{*}{ Palena Province } & Puelo - Cisnes & 3474 & 817.6 \\
\hline & & & West coast from $\mathrm{Vn}$. Yate to $\mathrm{Vn}$. Mentolat & 687 & 364.5 \\
\hline & & & Nevado Queulat & 37 & 102.8 \\
\hline \multirow{24}{*}{$\begin{array}{l}\text { Wet } \\
\text { Andes }\end{array}$} & \multirow{24}{*}{$\begin{array}{l}\text { Patagonia and Tierra } \\
\text { del Fuego }\end{array}$} & \multirow{7}{*}{$\begin{array}{l}\text { Northern Patagonia Icefield and } \\
\text { surrounding areas }\end{array}$} & West coast and Aysén & 1168 & 412.2 \\
\hline & & & Exploradores other than NPI & 294 & 86.8 \\
\hline & & & NPI main (Outlets) & 28 & 3758.9 \\
\hline & & & $\begin{array}{l}\text { NPI mountain glaciers connected other than } \\
\text { Outlets }\end{array}$ & 87 & 151.6 \\
\hline & & & West coast North of Fjord Calén (unconnected) & 626 & 175.0 \\
\hline & & & Baker other than NPI & 3353 & 1331.4 \\
\hline & & & Bravo and others north of Fjord Calén & 646 & 286.7 \\
\hline & & \multirow{8}{*}{$\begin{array}{l}\text { Southern Patagonia Icefield and } \\
\text { surrounding areas }\end{array}$} & Pascua other than SPI & 1144 & 302.9 \\
\hline & & & SPI main (Outlets to Pacific Ocean) & 39 & 8479.1 \\
\hline & & & $\begin{array}{l}\text { SPI mountain glaciers connected other than } \\
\text { Outlets }\end{array}$ & 287 & 1465.4 \\
\hline & & & West coast of SPI (unconnected) & 2647 & 348.8 \\
\hline & & & SPI (Combined East side*) & 5 & 215.6 \\
\hline & & & Serrano other than SPI & 415 & 133.1 \\
\hline & & & Última Esperanza (Mount Balmaceda and others) & 400 & 61.6 \\
\hline & & & Cordillera Sarmiento & 288 & 127.7 \\
\hline & & \multirow[t]{3}{*}{ Mainland north of Strait of Magellan } & $\begin{array}{l}\text { Other mountain glaciers north of Strait of } \\
\text { Magellan }\end{array}$ & 737 & 120.4 \\
\hline & & & $\begin{array}{l}\text { Gran Campo Nevado (Outlets and mountain } \\
\text { glaciers) }\end{array}$ & 28 & 190.8 \\
\hline & & & Isla Riesco & 444 & 205.8 \\
\hline & & \multirow{6}{*}{$\begin{array}{l}\text { Archipelagos south of Strait of } \\
\text { Magellan down to Cape Horn }\end{array}$} & Other Archipelagos & 221 & 72.0 \\
\hline & & & Mountain glaciers of Tierra del Fuego & 894 & 826.1 \\
\hline & & & Cordillera Darwin (Outlets and mountain glaciers) & 172 & 1794 \\
\hline & & & Isla Desolación & 6 & 13.5 \\
\hline & & & Isla Santa Inés (Outlets and mountain glaciers) & 283 & 267.0 \\
\hline & & & Isla Hoste (Outlets and mountain glaciers) & 467 & 345.4 \\
\hline
\end{tabular}

*A portion of the drainage area of five east side glaciers contributing to the Atlantic Ocean.

of which $105.7 \mathrm{~km}^{2}$ (55\% of the zone) correspond to 1368 rock glaciers. Twelve glaciers, mostly found at the Altiplano, Copiapó and Huasco catchments, are larger than $1 \mathrm{~km}^{2}$.

Tropical glaciers are located north of the Arid Diagonal (Vuille, 2011), as ice-covered volcanoes of northernmost Chilean Altiplano such as Pomerape, Parinacota, Acotango and Guallatire. Cerro Sillajhuay $\left(19^{\circ} 45^{\prime}\right.$ S) contains the last glacier prior to the development of hyper-arid conditions further south. Tropical glaciers of the Chilean Altiplano $\left(17^{\circ} 30^{\prime}-19^{\circ} 45^{\prime} \mathrm{S}\right)$ amount to $<1 \%$ of the total glacierized area.

The driest part of the Desert Andes occurs between Cerro Aucanquilcha $\left(21^{\circ} 28^{\prime} \mathrm{S}\right)$, in the Loa catchment, and Llullaillaco volcano $\left(24^{\circ} 43^{\prime} \mathrm{S}\right)$ at the high plateau of Puna de Atacama where only rock glaciers can be found. Large rock glaciers have been observed at Cerro Aucanquilcha, San Pedro and San Pablo volcanoes (Payne, 1998).

In the Norte Chico, at the southern tip of the Arid Diagonal, relatively large glacierets appear at Llullaillaco volcano, Nevado Tres Cruces $\left(27^{\circ} 05^{\prime}\right.$ S) and Cerro Muerto. Mountain glaciers occur at Cerro El Potro $\left(28^{\circ} 23^{\prime}\right.$ S), in the Copiapó catchment, where Del Potro glacier,
$4.8 \mathrm{~km}^{2}$, is the largest one of the entire Norte Chico. Some other large glaciers of Norte Chico are Tronquitos, Maranceles and Estrecho. Glacier coverage decreases in the Elqui and Choapa catchments, covering altogether $22.3 \mathrm{~km}^{2}$.

Garín (1987) estimated $106.8 \mathrm{~km}^{2}$ in 92 ice-bodies between the Altiplano and Elqui catchment, which is lower than our estimate of $188.9 \mathrm{~km}^{2}$ distributed in 2057 icebodies for the same Andean area. In the case of Huasco catchment, 152 ice-bodies covering $23.17 \mathrm{~km}^{2}$ were identified using satellite data of 2004 (Nicholson and others, 2009), whereas we identified 334 ice-bodies covering 32.6 $\mathrm{km}^{2}$. Although former inventories are not directly comparable with our results, the reduction in glacierized area is interpreted as glacier shrinkage.

\section{Central Andes}

The glacierized area of the Central Andes is $869.5 \mathrm{~km}^{2}$, ca. $3.6 \%$ of the Chilean glacierized area, of which $289.9 \mathrm{~km}^{2}$ (33\% of the zone) correspond to 1472 rock glaciers. A 
Table 3. Number of glaciers per size class inventoried using 2000/ 2003 Landsat data

\begin{tabular}{lrr}
\hline $\begin{array}{l}\text { Size class } \\
\mathrm{km}^{2}\end{array}$ & Number & $\begin{array}{l}\text { Area } \\
\mathrm{km}^{2}\end{array}$ \\
\hline $0.01-0.049$ & 10707 & 259.4 \\
$0.05-0.099$ & 3364 & 259.5 \\
$0.1-0.24$ & 3868 & 621.8 \\
$0.25-0.49$ & 2246 & 800.7 \\
$0.5-0.99$ & 1575 & 1094.9 \\
$1-4.9$ & 1525 & 3113.9 \\
$5-9.9$ & 204 & 1362.9 \\
$10-49$ & 148 & 3047.3 \\
$50-99$ & 31 & 2011.7 \\
$100-499$ & 32 & 7044 \\
$500-999$ & 4 & 2845.1 \\
$>1000$ & 1 & 1246.9 \\
Total & 24005 & 23708 \\
\end{tabular}

number of 153 glaciers are larger than $1 \mathrm{~km}^{2}$, covering 489 $\mathrm{km}^{2}(57 \%$ of the zone) and 627 glaciers are larger than 0.25 $\mathrm{km}^{2}$, covering $708 \mathrm{~km}^{2}(82 \%)$. In this zone, glaciers with distinctive tongues reach significant dimensions $\left(>10 \mathrm{~km}^{2}\right)$ at three main catchments. The most glacierized one is Maipo with $388.3 \mathrm{~km}^{2}$ of glaciers, followed by Rapel with 292.3 $\mathrm{km}^{2}$ and Aconcagua with $135.8 \mathrm{~km}^{2}$, and together containing $95 \%$ of the glacierized area of the Central Andes. The mean elevation of glaciers is $3700 \mathrm{~m}$, which is relatively low and goes in line with the decrease in the elevation of the Andes southwards. $65 \%$ of the glaciers are oriented to the south and southeast.

The Juncal - Olivares glacier complex (ca. $72.8 \mathrm{~km}^{2}$ ) comprises the watershed between the Aconcagua and Maipo catchments. Other several large complexes located at Maipo catchment are Loma Larga - Morado; Tupungato; Marmolejo - San José; Bello - Pirámide; Argüelles and Maipo volcano. Picos del Barroso mountain complex comprises the watershed of Maipo and Rapel catchments, while the group of Palomo volcano with ca. $92.5 \mathrm{~km}^{2}$ is the largest complex of the Central Andes. Located at Rapel catchment, Universidad glacier, with $27.5 \mathrm{~km}^{2}$ is one of the largest of the Central Andes. A smaller group at Rapel catchment is the Tinguiririca complex, which contains several unnamed glaciers. Glacier coverage is reduced drastically at Maule and Mataquito catchments. At the Peteroa - Azufre complex, the southernmost large glaciers $\left(>5 \mathrm{~km}^{2}\right)$ of the Central Andes are found. In addition, few isolated icecovered volcanoes such as Descabezado Grande, Cerro Azul, Nevado Longaví and Nevados de Chillán still have a large coverage of glaciers.

In the Aconcagua catchment, Valdivia (1984) inventoried 267 ice-bodies with an area of $151.2 \mathrm{~km}^{2}$ using air photographs, and Bown and others (2008) 159 glaciers covering $121.2 \mathrm{~km}^{2}$ using satellite data of 2003. In the Maipo catchment, 647 glaciers were inventoried covering $421.9 \mathrm{~km}^{2}$ (Marangunic, 1979), and at Rapel catchment, 507 icebodies covering $328 \mathrm{~km}^{2}$ were inventoried (Caviedes, 1979; Valdivia, 1984). These earlier inventories also indicate generalized glacier shrinkage in the Central Andes.

\section{Lakes District and Palena Province}

Glaciers in the zone from Itata catchment to Cisnes catchment cover $1478.8 \mathrm{~km}^{2}$, representing ca. $6.3 \%$ of the
Chilean glacierized area. At the northern sector between the catchments of Itata and Petrohué, Lakes District contains 17 large ice-covered volcanoes such as Sierra Nevada, Villarrica, Mocho-Choshuenco and Osorno as well as Mount Tronador, covering together an area of $193.3 \mathrm{~km}^{2}$. A total glacierized area of $261.82 \mathrm{~km}^{2}$ was previously determined between Bío-Bío and Petrohué catchments (Rivera, 1989) confirming the glacier shrinkage trend also in this area. The largest glacier area, covering $1285 \mathrm{~km}^{2}$, is found at the southern sector between Cochamó and Cisnes catchments, including Yate, Michinmahuida, Corcovado and Melimoyu, four ice-covered volcanoes of Palena Province, where many small mountain glaciers also straddle the crest of the coastal range. In addition, Cordón Inexplorado, Cordón Pico Alto, Cordón Yelcho and Nevado Queulat are the largest inner ice-complexes contributing to Blanco, Puelo, Yelcho and Queulat catchments, respectively.

\section{Patagonian Andes and Tierra del Fuego}

From Aysén catchment southwards, the Andes range is characterized by a deeply indented glaciated coastline and its inner icefields. The Patagonian Andes represent $89.3 \%$ of the total glacierized area, covering ca. $21171 \mathrm{~km}^{2}$. At the western coastal range of Patagonia, the four ice-covered volcanoes Mentolat, Cay, Macá and Hudson and the Erasmo complex are the largest ice masses prior to the extent of the main Patagonian icefields.

The NPI and SPI are the largest ice masses, where the small number of 66 large outlet glaciers predominate. These calving glaciers cover a total area of $12138 \mathrm{~km}^{2}$, representing $\sim 51 \%$ of the Chilean glacierized area. In addition, we have to add 87 mountain glaciers connected with the main body of NPI, covering $151.6 \mathrm{~km}^{2} ; 2647$ mountain glaciers connected with the main body of the SPI, covering $1465.4 \mathrm{~km}^{2}$; and 2647 mountain glaciers on the west side of SPI, covering 348.8 $\mathrm{km}^{2}$. This large number of mountain glaciers located in the periphery of the main icefields and those other than icefields found at Baker, Pascua and Serrano catchments, have never previously been inventoried.

On the west maritime side, outlet glaciers directly reach sea-level in a fjord. On the other hand, east side continental outlets terminate in fresh water lakes and contribute to three large catchments such as Baker, Pascua and Serrano. In addition, smaller icefields with outlet glaciers larger than 100 $\mathrm{km}^{2}$ and many mountain glaciers also exist north and south of the Strait of Magellan, such as Gran Campo Nevado, Isla Santa Inés, Cordón Navarro, Cordillera Darwin and Isla Hoste.

\section{Glacier classification}

Land-terminating ice masses such as mountain and valley glaciers are widely spread along the country, predominating in number (5687) whereas 79 large calving glaciers of Patagonia and Tierra del Fuego represent $12848 \mathrm{~km}^{2}$ (54\% of glacierized area). Meltwater from land-terminating glaciers importantly contributes to run-off if they constitute a large ice-complex. On the other hand, calving glaciers of Patagonia have accounted for a major contribution to sea-level rise per unit area, which is larger than the contribution from Alaska's glaciers (e.g. Aniya, 1999; Rignot and others, 2003).

Identification of rock glaciers is not straightforward when only using optical imagery. Their distinction from debriscovered glaciers is important because rock glaciers contain 


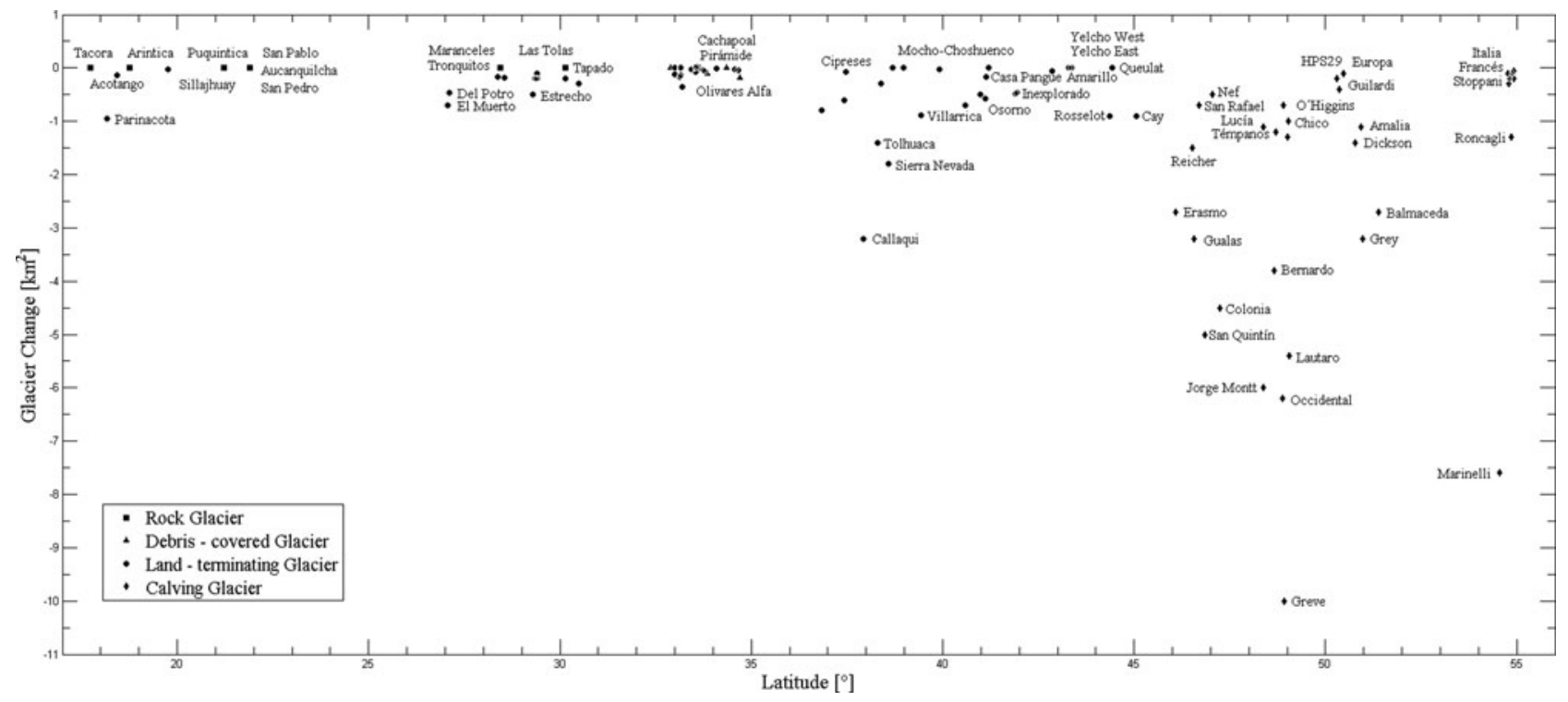

Fig. 6. Area changes between 2000/03 and 2015 for 98 glaciers across all glacierized regions and size classes. Rapid glacier changes have been observed from the Altiplano down to Cordillera Darwin. Decline in glacier area is mostly affecting to clean-ice land-terminating glaciers at different rates whereas debris-covered glaciers and rock glaciers in the Desert and Central Andes appear nearly unchanged in their extent. The uneven recession trend in the Patagonian Andes is explained by the dynamics of calving glaciers.

much less ice per volume thereby the total ice volume and its sea-level equivalent of a catchment can be overestimated. However, only further field-based surveys can investigate both the internal structure and ice content of a rock glacier, which are key factors in its dynamics and evolution (Hausmann and others, 2007).

Despite the fact that Gran Campo Nevado (Schneider and others, 2007) and Cordillera Darwin (Holmlund and Fuenzalida, 1995) have been classified as ice caps, we classified them as icefields (i.e. outlets and mountain glaciers) as well as Isla Santa Inés and Isla Hoste because the threshold of $50000 \mathrm{~km}^{2}$ to classify an ice cap (Benn and Evans, 2010), appears too large even for the entire glacierized area of the Southern Andes. While an ice cap is a dome-shaped ice mass with radial flow, a distinctive feature of an icefield is a large and flat accumulation area in which the catchment area may not be clearly delineated (Müller and others, 1977).

In flat areas where rock outcrops are absent, the location of the ice divides is not straightforward when ice flow data is lacking, so changes in drainage areas reflect trends mainly in ice dynamics rather than surface mass-balance processes alone (Mouginot and Rignot, 2015). Redefined icedivides and drainage areas from previous studies (e.g. Davies and Glasser, 2012; Casassa and others, 2014) have been reported for both the NPI and the SPI due to enhanced ice flow, meaning that changes in ice dynamics propagate far inside the accumulation areas (Mouginot and Rignot, 2015). However, for inventory purposes those changes take place in the inner accumulation areas, which does not largely alter the main glacierized area.

\section{Glacier surface conditions}

The total surface area of clean-ice in Chile reaches 20508 $\mathrm{km}^{2}, \sim 86 \%$ of the total glacierized area. It is mostly found in Patagonia and Tierra del Fuego as well as in mountain and valley glaciers in Lakes District and Palena Province and partially in the Central Andes. A small amount of clean-ice is found in the Desert Andes. The remaining
$15 \%$, including both rock glaciers and debris-covered glaciers, is largely found along the Desert Andes and Central Andes, up to the Maule catchment, where freezing temperatures by elevation and low snow-accumulation rates are characteristics. Due to loss of both continuity and elevation of the Andes, the transition to Mediterranean climate with a wetter summer precludes the occurrence of rock glaciers southwards. However, debris-covered areas can still be found in a wetter climate due to local conditions such as rock-fall and stagnation at Mount Tronador, as the case of Casa Pangue and Blanco glaciers. Large amount of debris coverage also exists in the ablation areas of Grosse, Exploradores, Fiero, Soler, Nef, Colonia, Pared Norte and Pared Sur glaciers within the NPI $\left(46^{\circ} 30^{\prime}-47^{\circ} \mathrm{S}\right)$, or Chico glacier $\left(49^{\circ} \mathrm{S}\right)$ within the $\mathrm{SPI}$, all of them flowing to continental east side.

\section{Recent glacier variations (2000/03-2015)}

Different data and methods (i.e. aerial photos, satellite images, algorithms, scale) yield different inventory measurements. However, when comparing the former inventories from the Dry Andes to Petrohué catchment with our results, there is a reduction in glacierized area from 1365 to 1200 $\mathrm{km}^{2}$ and an increase from 1751 to 4973 in the number of glaciers. Decrease in glacierized area is interpreted as glacier shrinkage and the increase in number is attributed to the fragmentation of ice-bodies. Although the existing inventories are not directly comparable, rapid glacier changes have been observed along the country, from the Altiplano down to Cordillera Darwin between 2000-03 and 2015 (Fig. 6).

Decline in glacier area is mostly affecting clean-ice (both land-terminating and calving) glaciers at different rates resulting in changes in their geometry such as marked ice front retreat (Figs. 7 and 8). The total area loss for 77 glaciers is $\sim-92.3 \pm 4.6 \mathrm{~km}^{2}$. However, 21 rock glaciers and debriscovered glaciers in the Desert and Central Andes appear nearly unchanged in their extent. Even though different type of glaciers can indicate distinct glacier sensitivities to 

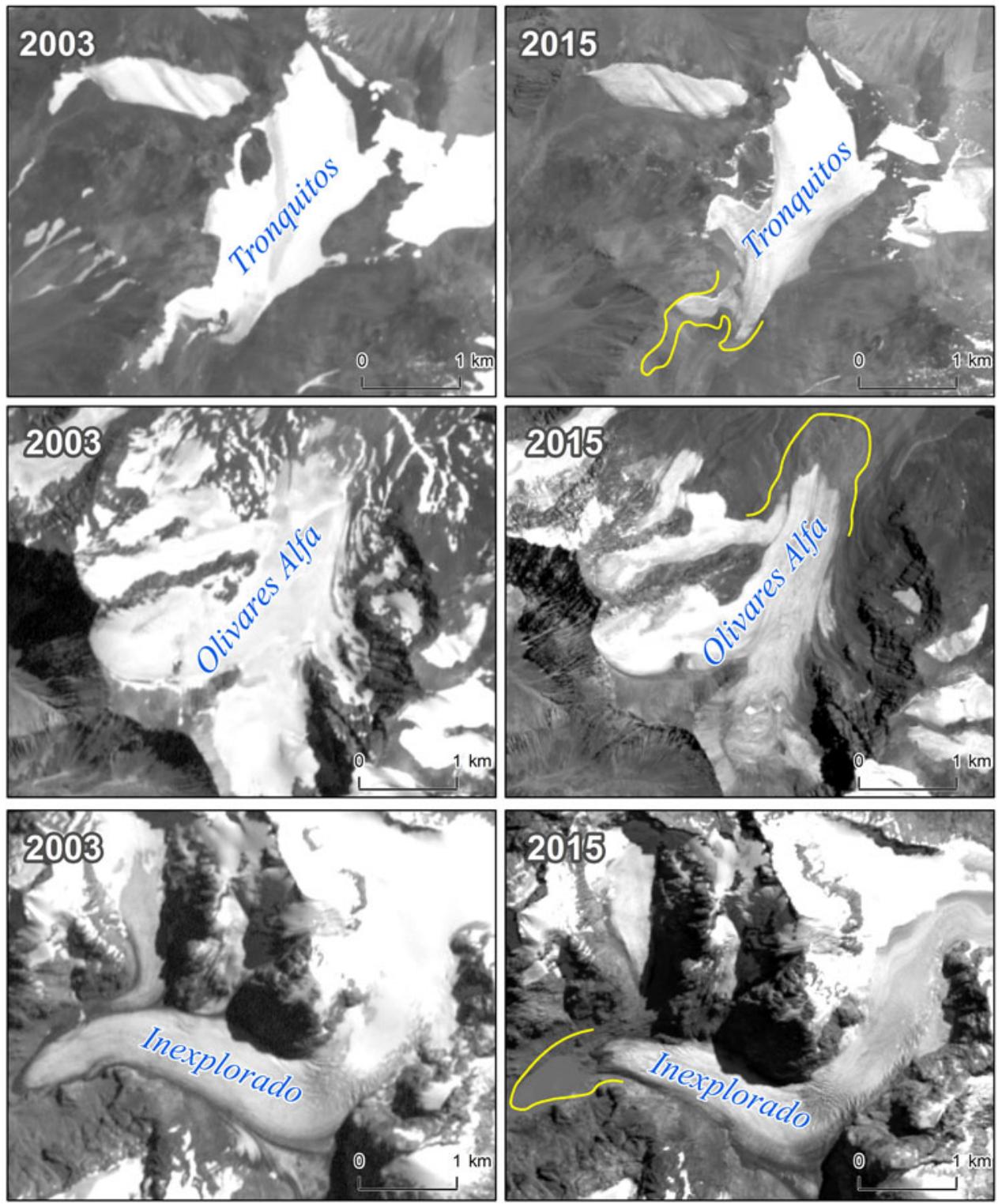

Fig. 7. Changes in terminus position between 2003 and 2015 for glaciers located at different zones. In the Desert Andes, Tronquitos glacier, one of the largest glaciers of Copiapó catchment, retreated $-0.18 \mathrm{~km}^{2}$. A larger retreat of $-0.36 \mathrm{~km}^{2}$ is observed at Olivares Alfa, a glacier located at the Maipo catchment, Central Andes. An unnamed tongue of the west side of Inexplorado complex at Palena Province retreated $-0.48 \mathrm{~km}^{2}$.

climatic regimes, local conditions are important in explaining current glacier response, because some large calving glaciers in Patagonia and Tierra del Fuego have been stable in recent years (e.g. Nef, O'Higgins) even in the zone where the largest retreating rates are observed (e.g. Colonia, Jorge Montt, Marinelli).

The glacierized areas of all ice-covered volcanoes of the Altiplano are shrinking. The largest retreat is observed at Parinacota volcano with $-0.9 \mathrm{~km}^{2}$, whereas at Acotango volcano and Cerro Sillajhuay a more moderate retreat of -0.13 and $-0.03 \mathrm{~km}^{2}$ is observed. However, large rock glaciers of Tacora volcano, Cerro Arintica, Cerro Aucanquincha, San Pedro and San Pablo volcanoes showed no frontal change.

At Norte Chico, a large retreat rate is observed at Del Potro glacier with $-0.17 \mathrm{~km}^{2}$ and Tronquitos glacier with -0.18 $\mathrm{km}^{2}$. Between Estrecho glacier and Cerro Volcán the retreat rate is more moderate $\left(\sim-0.5 \mathrm{~km}^{2}\right)$. Large rock glaciers such as Maranceles and Las Tolas at Copiapó, and Elqui catchments, respectively, also showed no frontal change.
Larger recession rates in the Central Andes are observed at Olivares Alfa glacier with $-0.36 \mathrm{~km}^{2}$ and Universidad glacier with $-0.17 \mathrm{~km}^{2}$ whereas other large glacier such as Cipreses, Cortaderal and Palomo decreased $<-0.04 \mathrm{~km}^{2}$. Debris-covered glaciers such as Pirámide and Cachapoal also showed no frontal change.

Ice-covered volcanoes and mountain glaciers of the Lakes District are retreating at contrasting rates. High retreat rates have been observed at Villarrica volcano with $-0.56 \mathrm{~km}^{2}$, at Mocho-Choshuenco volcano with $-0.02 \mathrm{~km}^{2}$ and at Osorno volcano with $-0.58 \mathrm{~km}^{2}$. At the northern side of Mount Tronador, the Casa Pangue glacier retreated -0.17 $\mathrm{km}^{2}$ whereas at its southern side, Blanco glacier showed no change even though they are both covered by debris.

Contrasting retreat rates are also observed at Palena Province as the case of Cordón Inexplorado, where two unnamed glaciers (west side) retreated -0.48 and -0.46 $\mathrm{km}^{2}$. However, two unnamed glaciers of Cordón Yelcho (west and east sides) showed no frontal change. A moderate rate is observed at Michinmahuida volcano (Amarillo glacier) 

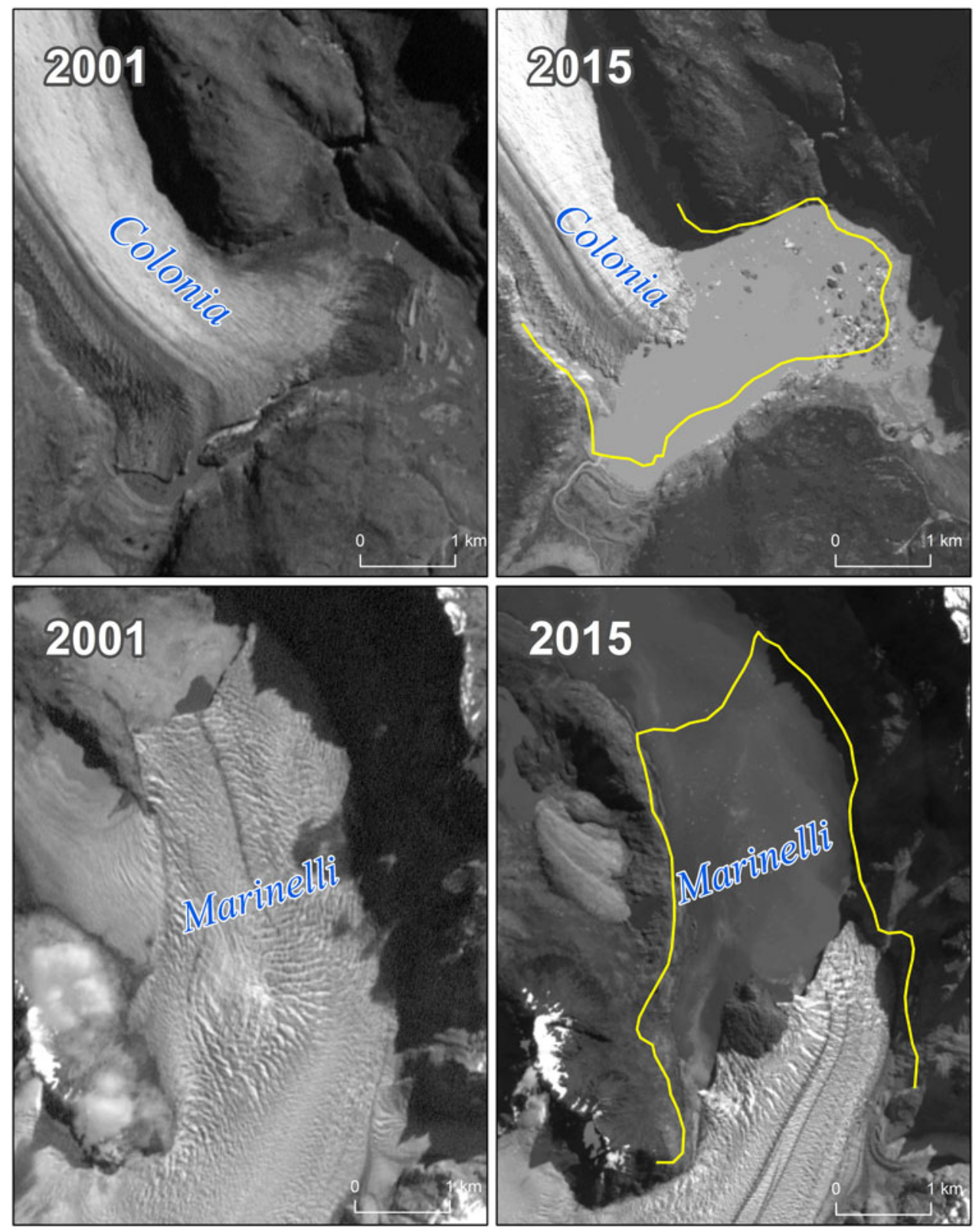

Fig. 8. The largest retreating rate is observed in the Patagonian Andes and Tierra del Fuego. Colonia glacier, one of the five largest outlet glaciers of the Northern Patagonia Icefield (NPI) retreated $-4.5 \mathrm{~km}^{2}$ and Marinelli glacier in the Cordillera Darwin, retreated $-7.0 \mathrm{~km}{ }^{2}$ between 2001 and 2015.

with $-0.05 \mathrm{~km}^{2}$, whereas the northern tongue of Queulat complex (Rosselot glacier) retreated $-0.9 \mathrm{~km}^{2}$ and contrastingly its southern tongue (Ventisquero Colgante del Queulat), showed no frontal change.

The magnitude of recession in Patagonia and Tierra del Fuego is the largest one in the Chilean Andes because of the large size and dynamics of calving glaciers (e.g. Warren and Aniya, 1999; Rivera and others, 2012). Large recession rates up to $-10 \mathrm{~km}^{2}$ in the case of Greve glacier and $-7.6 \mathrm{~km}^{2}$ for Marinelli in Cordillera Darwin are observed. Other west facing glaciers such as Gualas and San Quintin within NPI retreated -3.2 and -5.0 $\mathrm{km}^{2}$, respectively. However, on the east side of $\mathrm{NPI}, \mathrm{Nef}$ glacier retreated at a more moderate rate of $-0.5 \mathrm{~km}^{2}$, whereas Colonia glacier retreated at a larger rate of $-4.5 \mathrm{~km}^{2}$, a contrasting behavior of two neighboring glaciers.

\section{SUMMARY AND OUTLOOK}

The first comprehensive glacier inventory of Chile, which will be available to the scientific community, includes a large glacierized area south of $46^{\circ} \mathrm{S}$, especially along the Patagonian Andes and Tierra del Fuego. Large glacierized areas along the Altiplano, Palena Province and the periphery of the Patagonian icefields and surrounding areas are inventoried. Chilean glaciers, with an area of $23708 \mathrm{~km}^{2}$, represent nearly $80 \%$ of the glacierized area of the entire Southern Andes. This estimate is more than $2000 \mathrm{~km}^{2}$ larger than previous glacier compilations, and is a large portion of the glacierized area of all countries of South America.

Glaciers across all glacierized regions and size classes are retreating at different rates. The observed warming in Southern South America (Rosenblüth and others, 1997) and the consequent rise in the snowlines (Carrasco and others, 
2005) is interpreted as the main reason. However, the spatial pattern of glacier shrinkage across the Andes of Chile is explained by the contrasting response of debris-covered glaciers in the Desert and Central Andes compared to the large recession trend in Patagonia, which is enhanced by the dynamics of calving glaciers.

A recent warming of $+0.25{ }^{\circ} \mathrm{C}$ per decade in the Andes between $17^{\circ} \mathrm{S}$ and $37^{\circ} \mathrm{S}$ has been established on the basis of observational data and modeling (Falvey and Garreaud, 2009). MODIS data indicate a high variability in the snowcovered area and its depletion depending on wet or dry years (i.e. El Niño Southern Oscillation) (Minora and others, 2015). Scant geodetic mass-balance observations in the Central Andes indicate larger thinning rates (ca. $-2.2 \mathrm{~m} \mathrm{a}^{-1}$ ) on clean-ice glaciers whereas a debris-covered glacier showed no elevation change between 2009 and 2012 (Barcaza and others, 2015).

\section{AUTHOR CONTRIBUTION STATEMENT}

G.B. led the study and wrote the manuscript. S.N. and J.L.G. helped in writing and scientific discussion. All the other coauthors contributed to data processing and analyses.

\section{ACKNOWLEDGMENTS}

This research was supported by Dirección General de Aguas (DGA), Ministry of Public Works, Chile, from where this first national glacier inventory is available. S. U. Nussbaumer and J. L. García acknowledge support from the EPFL Leading House for scientific and bilateral cooperation between Switzerland and Chile. The support in data processing of Rodrigo Sáez, Claudio Durán, Andrés Ceballos, Camilo Muñoz, Miguel Barros, Carlos Mendoza, Tamsin Sepúlveda and Jorge Huenante, is greatly appreciated. Comments from Bruce H. Raup, National Snow and Ice Data Center (NSIDC), an anonymous reviewer and the scientific editor, Ian Allison, are greatly appreciated. Mr. Felipe Herrera (R.I.P.), a member of DGA staff who tragically died in 2012, worked in the identification of rock glaciers; this paper is dedicated to his memory.

\section{REFERENCES}

Aniya M (1988) Glacier inventory for the northern Patagonia icefield, Chile, and variations 1944/45 to 1985/86. Arct. Antarc. Alp. Res., 20(2), 179-187

Aniya M (1999) Recent glacier variations of the Hielos Patagónicos, South America, and their contribution to Sea-level change. Arct. Antarc. Alp. Res., 31(2), 165-173

Aniya M, Sato H, Naruse R, Skvarca P and Casassa G (1996) The use of satellite and airborne imagery to inventory outlet glaciers of the southern Patagonian icefield, South America. Photogramm. Eng. Remote Sens., 62(12), 1361-1369

Arendt A and 77 others (2015) Randolph Glacier Inventory - A Dataset of Global Glacier Outlines: Version 5.0 GLIMS Technical Report

Bahr DB and Radić V (2012) Significant contribution to total mass from very small glaciers. Cryosphere, 6, 763-770 (doi: 10.5194/tc-6-763-2012)

Barcaza G and 6 others (2015) Surface elevation change of Andean glaciers in central Chile, based upon airborne laser altimetry and ground-truth GPS measurements (Abstract 5649). Presented at 26th General Assembly, International Union of Geodesy and Geophysics
Benitez A (1980) Clasificación de cuencas hidrográficas de Chile. Publicación Interna CUH-1101.

Benn DI and Evans DJA (2010) Glaciers and glaciation. 2th edn., Hodder Education, London.

Benn D and 9 others (2012) Response of debris-covered glaciers in the Mount Everest region to recent warming, and implications for outburst flood hazards. Earth-Sci. Rev., 114(1-2), 156-174

Bliss A, Hock R and Cogley JG (2013) A new inventory of mountain glaciers and ice caps for the Antarctic periphery. Ann. Glaciol., 54(63), 191-199

Bolch T, Menounos B and Wheate R (2010) Landsat-based inventory of glaciers in western Canada, 1985-2005. Remote Sens. Environ., 114, 127-137 (doi: 10.1016/j.rse.2009.08.015)

Bown F, Rivera A and Acuña C (2008) Recent glacier variations at the Aconcagua basin, central Chilean Andes. Ann. Glaciol., 48, 43-48

Casassa G (1995) Glacier inventory in Chile: current status and recent glacier variations. Ann. Glaciol., 21, 317-322

Casassa G and Rivera A (2001) Campo de Hielo Sur: Su Historia. Anal. Inst. Patagon. Hum., 29, 29-78

Casassa $G$ and 5 others (2002) Inventory of glaciers in Isla Riesco, Patagonia, Chile, based on aerial photography and satellite imagery. Ann. Glaciol., 34, 373-378

Casassa G, Rodriguez JL and Loriaux T (2014) A new glacier inventory for the Southern Patagonia icefield and areal changes 19862000. In Kargel JS, Leonard GJ, Bishop MP, Kääb A and Raup BH eds. Global land Ice measurements from space. Springer, Heidelberg/Berlin, 639-660

Carrasco J, Casassa G and Rivera A (2002) Meteorological and climatological aspects of the southern Patagonia icefield. In Casassa G, Sepúlveda F and Sinclair R eds. The patagonian icefields: a unique natural laboratory for environmental and climate change studies. Kluwer Academic/Plenum Publishers, New York, 29-41

Carrasco J, Casassa G and Quintana J (2005) Changes of the $0{ }^{\circ} \mathrm{C}$ isotherm and the equilibrium line altitude in central Chile during the last quarter of the 20th century. Hydrol. Sci. J., 50(6), 933-948 doi 10.1623/hysj.2005.50.6.933)

Cogley JG and 10 others (2011) Glossary of glacier mass balance and related terms, IHP-VII Technical Documents in Hydrology No. 86, IACS Contribution No. 2, UNESCO-IHP, Paris

Caviedes C (1979) Inventario de glaciares en la hoya del río cachapoal y predicción de la escorrentía de deshielo; Andes Centrales (unpublished). Memoria, Escuela de Geología, Universidad de Chile, 217 pp

Davies BJ and Glasser NF (2012) Accelerating shrinkage of Patagonian glaciers from the Little Ice Age (AD 1870) to 2011, J. Glaciol., 58(212), 1063-1084 (doi: 10.3189/2012JoG12J026)

Falvey M and Garreaud RD (2009) Regional cooling in a warming world: recent temperature trends in the southeast Pacific and along the west coast of subtropical South America (1979-2006). J. Geophys. Res., 114, D04102 (doi: 10.1029/2008JD010519)

Favier V, Falvey M, Rabatel A, Praderio E and López D (2009) Interpreting discrepancies between discharge and precipitation in high altitude area of Chile's Norte Chico region $\left(26^{\circ} \mathrm{S}-32^{\circ} \mathrm{S}\right)$. Water Resour. Res.., 45, W02424 (doi: 10.1029/ 2008WR006802)

Frey H, Paul F and Strozzi T (2012) Compilation of a glacier inventory for the western Himalayas from satellite data: methods, challenges, and results. Remote Sens. Environ., 124, 832-843 (doi: 10.1016/j.rse.2012.06.020)

Garín C (1987) Inventario de glaciares de los Andes Chilenos desde los $18^{\circ}$ a los $32^{\circ}$ de latitud sur. Rev. Geog. Norte Grande, 14, 34-48

Garreaud R (2009) The Andes climate and weather. Adv. Geosci., 22, 3-11

Giardino JR, Ragmi NR and Vitek JD (2011) Rock glaciers. In Singh VP, Singh P, Haritashya UK eds. Encyclopedia of snow, ice and glaciers. Springer, Dordrecht, 943-948

Ginot P, Kull C, Schotterer C, Schwikowski M and Gaggeler HW (2006) Glacier mass balance reconstruction by sublimation 
induced enrichment of chemical species on Cerro Tapado (Chilean Andes). Clim. Past, 2, 21-30

Grinsted A (2013) An estimate of global glacier volume. Cryosphere, $7,141-151$

Hausmann H, Krainer K, Brückl E and Mostler W (2007) Internal structure and Ice content of reichenkar rock glacier (Stubai Alps, Austria) assessed by geophysical investigations. Permafrost Periglacial Process., 18, 351-367

Holmlund $\mathrm{P}$ and Fuenzalida $\mathrm{H}$ (1995) Anomalous glacier responses to 20th century climatic changes in darwin Cordillera, southern Chile. J. Glaciol., 41(139), 465-473

Huss $M$ and Farinotti D (2012) Distributed ice thickness and volume of all glaciers around the globe J. Geophys. Res., 117, F04010 (doi: 10.1029/2012JF002523)

IGOS/Integrated Global Observing Strategy (2007) A cryosphere theme report for the IGOS partnership. WMO/TD-No1405

Kääb A, Paul F, Maisch M, Hoelzle M and Haeberli W (2002) The new remote-sensing-derived Swiss glacier inventory: il. First results. Ann. Glaciol., 34, 362-366

Kammer K (1998) Rock glaciers, western Andes, Chile, Version 1. NSIDC, National Snow and Ice Data Center, Boulder Colorado, USA

Kirkbride M (2011) Debris-covered glaciers. In Singh VP, Singh P, Haritashya UK eds. Encyclopedia of snow, Ice and glaciers. Springer, Dordrecht, 190-192

Lliboutry L (1998) Glaciers of South America. In Williams RS, Jr and Ferrigno JG eds. Satellite image atlas of glaciers of the world. US Geological Survey Professional Paper, 1386-I-6, 109-206

Marangunic C (1979) Inventario de glaciares. Hoya del río maipo. Dirección General de Aguas, Publicación G-2, Santiago

Marzeion B, Jarosch AH and Hofer M (2012) Past and future sealevel change from the surface mass balance of glaciers. Cryosphere, 6, 1295-1322

Minora U and 7 others (2015) 2008-2011 snow covered area (SCA) variability over 18 watersheds of the central Chile through MODIS data. Geog. Fis. Dinam. Quat., 38, 169-174

Mouginot J and Rignot E (2015) Ice motion of the Patagonian icefields of South America: 1984-2014. Geophys. Res. Lett., 42 (5), 1441-1449 (doi: 10.1002/2014GL062661)

Müller F, Caflisch T and Müller G (1977) Instructions for compilation and assemblage of data for a world glacier inventory. Temporal Technical Secretariat for the World Glacier Inventory (TTS/ WGI), Zürich

Nicholson L and 5 others (2009) Glacier inventory of the upper huasco valley, norte Chico, Chile: glacier characteristics, glacier change and comparison with central Chile. Ann. Glaciol., 50(53), 111-118

Noveroy C (1987) Inventario de glaciares de la hoya del río mataquito. Dirección General de Aguas, Publicación interna, EH 87/1, 38

Ohata $\mathrm{T}$ and 5 others (1985) The east-west contrast in meteorological conditions and its effect on glacier ablation. In Nakajima C ed. Glaciological studies in patagonia northern icefield, data center for glacier research, Japanese Society of Snow and Ice, Report, vol. 8, 52-56

Paul F and Andreassen LM (2009) A new glacier inventory for the svartisen region, Norway, from landsat ETM+ data: challenges and change assessment. J. Glaciol., 55(192), 607-618

Paul F and Mölg N (2014) Hasty retreat of glaciers in northern patagonia from 1985 to 2011, J. Glaciol., 60(224), 1033-1043 (doi: 10.3189/2014JoG14J104)

Paul F and 9 others (2009) Recommendations for the compilation of glacier inventory data from digital sources. Ann. Glaciol., 50(53), 119-126

Paul F and 19 others (2013) On the accuracy of glacier outlines derived from remote-sensing data. Ann. Glaciol, 54(63), 171-182
Payne D (1998) Climatic implications of rock glaciers in the arid Western Cordillera of the Central Andes. Glacial Geology and Geomorphology

Pfeffer TW and 19 others (2014) The Randolph Glacier Inventory: a globally complete inventory of glaciers. J. Glaciol., 60 (221), 537552 (doi: 10.3189/2014JoG13J176)

Raup BH and 5 others (2007) The GLIMS geospatial glacier database: a new tool for studying glacier change. Glob. Planet. Change, 56, 101-110 (doi: 10.1016/j.gloplacha.2006.07.018)

Rignot E, Rivera A and Casassa G (2003) Contribution of the Patagonia icefields of South America to sea level rise. Science, 302(5644), 434-437

Rivera A (1989) Inventario de glaciares entre las cuencas de los ríos Bio Bio y petrohué. Su relación con el volcanismo activo: Caso del volcán Lonquimay. Memoria para optar al título de Geógrafo, Universidad de Chile, Santiago

Rivera A, Casassa G, Acuña C and Lange H (2000) Variaciones recientes de glaciares en Chile. Rev. Invest. Geogr., 34, 29-60

Rivera A, Acuña C, Casassa G and Bown F (2002) Use of remote sensing and field data to estimate the contribution of Chilean glaciers to the sea level rise. Ann. Glaciol., 34, 367-372

Rivera A, Benham T, Casassa G, Bamber J and Dowdeswell JA (2007) Ice elevation and areal changes of glaciers from the northern Patagonia icefield, Chile. Clob. Planet. Change, 59, 126137

Rivera A, Corripio J, Bravo C and Cisternas S (2012) Glaciar Jorge Montt (Chilean Patagonia) dynamics derived from photos obtained by fixed cameras and satellite image feature tracking. Ann. Glaciol., 53(60), 147-155 (doi: 10.3189/2012AoG60A152)

Rosenblüth B, Fuenzalida H and Aceituno P (1997) Recent temperature variations in Southern South America. Int. J. Climatol., 17, 67-85 (doi: 10.1002/(SICl)1097-0088(199701)17:13.0.CO;2-G)

Sakai A, Takeuchi N, Fujita K and Nakawo M (2000) Role of supraglacial ponds in the ablation process of a debris-covered glacier in the Nepal Himalayas. In Nakawo M, Raymond CF and Fountain A eds. Debris-covered glaciers. IAHS Publ. No. 265, 119-130

Schiefer E, Menounos B and Wheate R (2008) An inventory and morphometric analysis of British Columbia glaciers, Canada. J. Glaciol., 54(186), 551-560

Schneider C, Schnirch M, Acuña C, Casassa G and Killian R (2007) Glacier inventory of the Gran Campo Nevado Ice Cap in the southern Andes and glacier changes observed during recent decades. Glob. Planet. Change, 59, 87-100

UNESCO/International Association of Scientific Hydrology (IASH) (1970) Perennial ice and snow masses: a guide for compilation and assemblage of data for a world inventory. UNESCO/ Technical Papers in Hydrology 1, Paris

Valdivia P (1984) Inventario de glaciares, Andes de Chile central (32-35lat. S). hoyas de los ríos aconcagua, maipo, cachapoal y tinguiririca. Jornadas de Hidrología de Nieves y Hielos en América del Sur. Programa Hidrológico Internacional, Santiago de Chile, 1, 6.1-6.24

Vuille M (2011) Andean glaciers. In Singh VP, Singh P, Haritashya UK eds. Encyclopedia of snow, Ice and glaciers, Springer, Dordrecht, 40-43

Warren C and Aniya M (1999) The calving glaciers of Southern South America. Glob. Planet. Change, 22, 59-77 (doi. org/ 10.1016/S0921-8181(99)00026-0)

Warren C and Sugden D (1993) The Patagonian icefields: a glaciological review. Arct. Alp. Res., 25(4), 316-331

Zemp M, Hoelzle M and Haeberli W (2009) Six decades of glacier mass-balance observations: a review of the worldwide monitoring network. Ann. Glaciol., 50, 101-111 